\title{
PENGARUH AKTIVITAS MANUSIA TERHADAP PERUBAHAN KUALITAS UDARA
}

\author{
Dwicahyo Karunia \\ Jurusan Teknik Lingkungan, Fakultas Arsitektur Lanskap dan Teknologi Lingkungan, \\ Universitas Trisakti, Jakarta, Indonesia
}

Email korespondensi: dwicahyo08212017@std.trisakti.ac.id

\begin{abstract}
ABSTRAK
Tingginya laju pertumbuhan penduduk, membuat kebutuhan akan penyokong kehidupan semakin tinggi, sebagai contoh adalah kebutuhan akan ruang. Maka, udara sebagai komponen yang penting dalam kehidupan, namun rentan terhadap perubahan akibat dari aktivitas manusia, perlu dipelihara dan ditingkatkan kualitasnya sehingga mampu memberikan daya dukung bagi makhluk hidup secara optimal. penulisan karya ilmiah ini bertujuan untuk mengetahui pengaruh aktivitas manusia terhadap perubahan kualitas udara ambien. Udara adalah campuran gas yang terdapat pada lapisan yang mengelilingi bumi. Komponen yang konsentrasinya paling bervariasi yaitu uap air dan $\mathrm{CO}_{2}$, kegiatan yang berpotensi menaikkan konsentrasi $\mathrm{CO}_{2}$ seperti pembusukan sampah tanaman, pembakaran atau sekumpulan massa manusia di dalam ruang terbatas yaitu karena proses pernapasan. Udara ambien adalah udara bebas di permukaan bumi pada lapisan troposfir yang dibutuhkan dan mempengaruhi kesehatan manusia, makhluk hidup dan unsur lingkungan hidup lainnya. Pencemaran udara adalah bertambahnya bahan atau substrat fisik atau kimia ke dalam lingkungan udara normal yang mencapai sejumlah tertentu, sehingga dapat dideteksi oleh manusia (yang dapat dihitung dan diukur) serta dapat memberikan efek pada manusia, binatang, vegetasi dan material. efek bahan pencemar udara secara umum terhadap kehidupan manusia, antara lain meningkatkan angka kesakitan dan kematian pada manusia, flora dan fauna, mempengaruhi kuantitas dan kualitas matahari yang sampai ke permukaan bumi, mempengaruhi dan mengubah iklim akibat terjadinya peningkatan kadar CO di udara. Maka, aktivitas manusia dapat berpengaruh dalam perubahan kualitas udara.
\end{abstract}

\section{Kata Kunci: kualitas udara; pencemaran udara; aktivitas manusia}

\section{PENDAHULUAN}

Tingginya laju pertumbuhan penduduk, membuat kebutuhan akan penyokong kehidupan semakin tinggi, sebagai contoh adalah kebutuhan akan ruang. Maka, udara sebagai komponen yang penting dalam kehidupan, namun rentan terhadap perubahan akibat dari aktivitas manusia, perlu dipelihara dan ditingkatkan kualitasnya sehingga mampu memberikan daya dukung bagi makhluk hidup secara optimal.

Sebanyak 99\% udara yang kita hirup berupa gas oksigen dan nitrogen. Gas-gas lain yang dihirup berkisar dalam jumlah yang sangat sedikit. Beberapa hasil penelitian melaporkan bahwa diantara gas yang sangat sedikit tersebut diidentifikasi sebagai gas pencemar. gas pencemar tersebut dapat berasal dari asap kendaraan, gas buangan pabrik, pembangkit listrik, larutan pembersih dan sebagainya yang berhubungan erat dengan aktivitas manusia.

Sebagai contoh, Jakarta yang merupakan ibukota Negara Indonesia yang memiliki luas sekitar 661,52 $\mathrm{km}^{2}$ dengan jumlah penduduk berjumlah 9.988.329 jiwa (2013) berdasarkan data Badan Pusat Statistik 2013. Jakarta memiliki suhu udara yang panas dan kering atau beriklim topis. Jakarta mengalami puncak musim penghujan bulan Januari dan Februari dengan rata-rata hujan $350 \mathrm{~mm}$ dengan suhu rata-rata $27^{\circ} \mathrm{C}$. Pada musim kemarau pada bulan Agustus dengan rata-rata curah hujan $60 \mathrm{~mm}$. Suhu rata-rata tahunan berkisar antara $25^{\circ}-38^{\circ} \mathrm{C}\left(77^{\circ}-100^{\circ} \mathrm{F}\right)$.

Jakarta menjadi kota yang memiliki perkembangan dan kemajuan yang sangat pesat diberbagai bidang dan sektor dibandingkan dengan kota-kota lain di Indonesia. Sehingga muncul berbagai permasalahan kota, salah satunya adalah pembangunan tempat tinggal. Akibat dari pembangunan tersebut, menyebabkan penurunan kualitas udara ambien. 
Pertumbuhan penduduk yang begitu cepat dan pesat, sebaiknya diiringi dengan upaya pemantauan kualitas udara perlu dilakukan agar dapat mengetahui tingkat kualitas udara pada daerah studi dengan melakukan pengukuran tingkat kualitas udara.

Tujuan dari penulisan karya ilmiah ini adalah untuk mengetahui pengaruh aktivitas manusia terhadap perubahan kualitas udara ambien.

\section{TINJAUAN PUSTAKA}

\section{Udara}

Udara adalah campuran gas yang terdapat pada lapisan yang mengelilingi bumi. Komponen yang konsentrasinya paling bervariasi yaitu uap air dan $\mathrm{CO}_{2}$, kegiatan yang berpotensi menaikkan konsentrasi $\mathrm{CO}_{2}$ seperti pembusukan sampah tanaman, pembakaran atau sekumpulan massa manusia di dalam ruang terbatas yaitu karena proses pernapasan (Agusnar, 2007).

Udara ambien adalah udara bebas di permukaan bumi pada lapisan troposfir yang dibutuhkan dan mempengaruhi kesehatan manusia, makhluk hidup dan unsur lingkungan hidup lainnya (Perda DKI Jakarta No. 2 Tahun 2005).

\section{Sumber Pencemaran Udara}

Pencemaran udara adalah masuk atau dimasukkannya zat, energi atau komponen lain ke dalam udara ambien oleh kegiatan manusia, sehingga mutu udara ambien turun sampai ke tingkat tertentu yang menyebabkan udara ambien tidak dapat memenuhi fungsinya (Perda DKI Jakarta No. 2 Tahun 2005).

Pencemaran udara adalah bertambahnya bahan atau substrat fisik atau kimia ke dalam lingkungan udara normal yang mencapai sejumlah tertentu, sehingga dapat dideteksi oleh manusia (yang dapat dihitung dan diukur) serta dapat memberikan efek pada manusia, binatang, vegetasi dan material (Chambers dan Masters dalam Mukono, 2006).

Pencemaran udara adalah terdapatnya bahan kontaminan di atmosfer karena ulah manusia (man made), yang membedakan pencemaran udara alamiah dan pencemaran udara di tempat kerja (occupational air pollution) (Mukono, 2006).

Sumber pencemar dapat diartikan setiap usaha dan/atau kegiatan yang mengeluarkan bahan pencemar ke udara yang menyebabkan udara tidak dapat berfungsi sebagaimana mestinya (Perda DKI Jakarta No. 2 Tahun 2005 tentang Pengendalian Pencemaran Udara). Klasifikasi sumber pencemar udara antara lain sebagai berikut:

Berdasarkan asal-usul, sumber pencemaran udara dapat dibagi menjadi: Sumber alamiah yaitu berasal dari fenomena alam yang terjadi seperti letusan gunung berapi; dan sumber antropogenik yaitu bersumber dari segala macam kegiatan manusia yang menghasilkan emisi gas buang terutama akibat kegiatan transportasi dan industri.

Berdasarkan letak: Pencemar udara dalam ruang yaitu pencemaran udara yang terjadi di dalam ruang yang dapat muncul akibat kegiatan manusia dalam ruangan seperti memasak, serta penggunaan bahan-bahan kimia dalam ruangan seperti cat, pewangi ruangan dan semprotan pembasmi serangga; dan pencemar udara di luar ruang pencemaran yang terjadi di luar ruangan, cenderung akibat kegiatan di luar ruangan seperti kegiatan transportasi.

Berdasarkan pergerakan: sumber bergerak seperti kendaraan bermotor; dan sumber tidak bergerak seperti pabrik dan tempat pembakaran sampah. Berdasarkan bentuk fisik pencemar dan susunan 
kimianya: polutan gas seperti Ammonia, $\mathrm{SO}_{2}, \mathrm{CO}$ dan $\mathrm{NOx}$; dan partikulat contohnya adalah TSP dan debu.

Berdasarkan pola emisinya: titik yaitu pola emisi bersumber dari 1 titik saja seperti cerobong asap; garis yaitu pola garis seperti pada jalan raya dengan volume kendaraan cukup tinggi; dan area yaitu pola emisi area dapat bersumber dari pola titik dalam jumlah banyak pada satu batasan area.

Berbagai aktivitas manusia mulai dari pemukiman, transportasi, industry dan lainnya menjadi sumber utama pencemaran udara (Agustine et al, 2017). Temuan Corman dan Masters dalam Mukono (2008), asal pencemar udara dapat diterangkan dengan 3 (tiga) proses yaitu atrisi (attrition) penguapan (vaporization) dan pembakaran (combustion), dari ketiga proses tersebut pembakaran merupakan proses yang sangat dominan dalam kemampuannya menimbulkan bahan polutan.

\section{Dampak Pencemaran Udara}

Menurut Baku Mutu Udara Ambien (BMUA) nasional di dalam Peraturan Pemerintah tentang Pengendalian Pencemaran Udara (PP Nomor 41 tahun 1999). Baku mutu ini memiliki 9 parameter yang berlaku untuk menilai kondisi udara ambient secara umum, yaitu sulfur-dioksida $\left(\mathrm{SO}_{2}\right)$, karbon monoksida $(\mathrm{CO})$, nitrogen dioksida $\left(\mathrm{NO}_{2}\right)$, ozon $\left(\mathrm{O}_{3}\right)$, hidrokarbon $(\mathrm{HC}), \mathrm{PM}_{10}, \mathrm{PM}_{2,5}$, TSP (debu), $\mathrm{Pb}$ (timah hitam), dustfall (debu jatuh). Kesembilan polutan ini dianggap sebagai polutanpolutan yang memiliki pengaruh langsung dan signifikan pada kesehatan manusia.

1. Karbon monoksida (CO)

Senyawa tidak berbau, tidak berasa dan pada suhu udara normal berbentuk gas tidak berwarna. Dihasilkan dari proses pembakaran bahan bakar fosil yang tidak sempurna, seperti bensin, minyak dan kayu bakar. Juga diproduksi dari pembakaran produk-produk alam dan sintesis, termasuk rokok. Konsentrasi rendah dapat menyebabkan pusing dan keletihan, konsentrasi tinggi dapat menyebabkan kematian (Kementerian Lingkungan Hidup, 2007).

2. Nitrogen dioksida $\left(\mathrm{NO}_{2}\right)$

Gas ini berwarna coklat kemerahan dan berbau tajam. Terutama dari proses pembakaran bahan bakar fosil, seperti bensin, batubara dan gas alam. $\mathrm{NO}_{2}$ bisa berasal dari oksidasi dengan kandungan $\mathrm{N}$ dalam bahan bakar dan juga oksidasi dengan $\mathrm{N}$ udara karena panas. $\mathrm{NO}_{2}$ bersifat racun terutama terhadap paru. Paru-paru yang terkontaminasi dengan gas NOx akan mengalami pembengkakan. Pada konsentrasi $\mathrm{NO}_{2}>100$ ppm kebanyakan hewan akan mati (Kementerian Lingkungan Hidup, 2007).

3. Sulfur dioksida $\left(\mathrm{SO}_{2}\right)$

Gas tidak berwarna, berbau dalam konsentrasi pekat. Banyak dihasilkan dari pembakaran bahan bakar yang mengandung sulfur, misalnya solar dan batubara. Menyebabkan sesak nafas bahkan kematian pada manusia dan juga pada hewan. Pada tumbuhan, menghambat fotosintesis, proses asimilasi dan respirasi. Merusak cat pada bangunan akibat reaksinya dengan bahan dasar cat dan timbal oksida $(\mathrm{PbO})$. Gas $\mathrm{SO}_{2}$ adalah kontributor utama hujan asam (Kementerian Lingkungan Hidup, 2007).

4. Debu Jatuh (Dustfall)

Partikel berukuran diatas 100 mikron. Secara alamiah dihasilkan dari debu tanah kering yang terbawa oleh angin atau berasal dari muntahan letusan gunung berapi. Juga pembakaran yang tidak sempurna dari bahan bakar yang mengandung senyawa karbon murni atau bercampur dengan gas-gas organik seperti halnya penggunaan mesin disel yang tidak terpelihara dengan baik (Kementerian Lingkungan Hidup, 2007).

5. Total Suspended Particulate (TSP)

Partikulat adalah padatan atau cairan di udara dalam bentuk asap, debu dan uap. Komposisi dan ukuran partikulat sangat berperan dalam menentukan pajanan. Ukuran partikulat debuyang membahayakan kesehatan umumnya berkisar 0,1 mikron - 10 mikron. Partikulat jugamerupakan sumber utama haze (kabut asap) yang menurunkan visibilitas. $\mathrm{PM}_{10}$ berukuran 
$\leq 10$ mikron. Mengganggu saluran pernapasan bagian atas dan menyebabkan iritasi. $\mathrm{PM}_{2,5}$ berukuran $\leq 2,5$ mikron. Langsung masuk ke dalam paru-paru dan mengendap di alveoli (Kementerian Lingkungan Hidup, 2007).

6. Ozon $\left(\mathrm{O}_{3}\right)$

Pada lapisan troposfer terbentuknyaO $\mathrm{O}_{3}$ akibat adanya reaksi fotokimia pada senyawa oksida nitrogen (NOx) dengan bantuan sinar matahari. Konsentrasi ozon yang tinggi dapat menyebabkan gangguan pada sistem pernafasan, serangan jantung dan kematian. Sebaliknya, di lapisan stratosfer keberadaan ozon sangat dibutuhkan untuk 'menyelimuti' permukaan bumi dari radiasi sinar ultraviolet (Kementerian Lingkungan Hidup, 2007).

7. Klorida

Gas berwarna hijau, bau sangat menyengat. Efek samping dari proses pemutihan (bleaching) dan produksi zat/ senyawa organik yang mengandung klor. Menyebabkan iritasi mata. Jika masuk dalam jaringan paru-paru dan bereaksi dengan ion hidrogen akan membentuk asam klorida yang bersifat sangat korosif dan menyebabkan iritasi dan peradangan saluran pernapasan (Kementerian Lingkungan Hidup, 2007).

8. Hidrokarbon (HC)

Jika berbentuk gas di udara umumnya tergolong sebagai Volatile Organic Compounds (VOC). Bentuk cair menjadi semacam kabut minyak. Jika padatan akan membentuk debu. Berasal dari industri plastik, resin, pigmen, zat warna, pestisida, karet, aktivitas geothermal, pembuangan sampah, kebakaran hutan serta transportasi. Di udara akan bereaksi denganbahan lain dan membentuk Polycyclic Aromatic Hidrocarbon (PAH), bila masuk dalam paru-paru menimbulkan luka dan merangsang terbentuknya sel-sel kanker (Kementerian Lingkungan Hidup, 2007).

9. Timbal $(\mathrm{Pb})$

Logam lunak yang berwarna kebiru-biruan atau abu-abu keperakan. Sangat beracun dan menyebabkan berbagai dampak kesehatan terutama pada anak-anak. Dapat menyebabkan kerusakan sistem syaraf dan pencernaan, sedangkan berbagai bahan kimia yang mengandung timbal dapat menyebabkan kanker (Kementerian Lingkungan Hidup, 2007).

\section{Klasifikasi Bahan Pencemar Udara}

Menurut Mukono (2006), bahan pencemar udara atau polutan dapat dibagi menjadi 2 (dua) bagian, yaitu:

Polutan primer yang merupakan polutan yang dikeluarkan langsung dari sumber tertentu dan dapat berupa gas, terdiri dari senyawa karbon, senyawa sulfur, senyawa nitrogen, dan senyawa halogen; serta partikel yang atmosfer mempunyai karakteristik spesifik, dapat berupa zat padat maupun suspensi aerosol cair. Bahan partikel tersebut dapat berasal dari proses kondensasi, proses dispersi (proses menyemprot) maupun proses erosi bahan tertentu. Asap seringkali dipakai untuk menunjukkan campuran bahan partikulat, uap, gas dan kabut.

Polutan Sekunder, mempunyai sifat fisik dan sifat kimia yang tidak stabil, biasanya terjadi karena reaksi dari dua atau lebih bahan kimia di udara, misalnya reaksi foto kimia, sebagai contoh adalah disosiasi $\mathrm{NO}_{2}$ yang menghasilkan $\mathrm{NO}$ dan $\mathrm{O}$ radikal. Proses kecepatan dan arah reaksinya dipengaruhi oleh beberapa faktor, antara lain: Konsentarsi relatif dari bahan reaktan, derajat foto aktivasi, kondisi iklim, topografi lokal dan adanya embun. Termasuk dalam polutan sekunder ini adalah ozon dan formaldehida.

\section{PENUTUP}

Berdasarkan studi pustaka yang dilakukan, dapat disimpulkan bahwa aktivitas manusia dapat berpengaruh dalam perubahan kualitas udara, sehingga perlu dilakukan penelitian lebih lanjut pengaruh aktivitas manusia terhadap perubahan kualitas udara. 


\section{DAFTAR PUSTAKA}

Agusnar, H. 2007. Kimia Lingkungan. USU Press. Medan.

Agustine, I., et al. 2017. Application of Open Air Model (R Package) to Analyze Air Pollution Data. Universitas Trisakti. Jakarta, Indonesia.

doi: http://dx.doi.org/10.25105/urbanenvirotech.v1i1.2430

Anonim. 1999. Peratuan Pemerintah No. 41 Tahun 1999 Tentang Pengendalian Pencemaran Udara.

Anonim. 2005. Peraturan Daerah DKI Jakarta No. 2 Tahun 2005 tentang Pengendalian Pencemaran Udara.

Deputi bidang lingkungan. 2007. Memprakirakan Dampak Lingkungan Kualitas Udara. Jakarta. Mukono, J. 2006. Prinsip Dasar Kesehatan Lingkungan. Airlangga University Press. Surabaya.

Mukono, J. 2008. Pencemaran Udara dan Pengaruhnya Terhadap Gangguan Saluran Pernafasan. Airlangga University Press. Surabaya.

Sarudji, D. 2010. Kesehatan Lingkungan. Karya Putri Darwati. Bandung. 